\title{
NEXRAD Quantitative Precipitation Estimates, Data Acquisition, and Processing for the DuPage County, Illinois, Streamflow- Simulation Modeling System
}

Next-Generation Radar (NEXRAD) has become an integral component in the estimation of precipitation (Kitzmiller and others, 2013). The high spatial and temporal resolution of NEXRAD has revolutionized the ability to estimate precipitation across vast regions, which is especially beneficial in areas without a dense rain-gage network. With the improved precipitation estimates, hydrologic models can produce reliable streamflow forecasts for areas across the United States. NEXRAD data from the National Weather Service (NWS) has been an invaluable tool used by the U.S. Geological Survey (USGS) for numerous projects and studies; NEXRAD data processing techniques similar to those discussed in this Fact Sheet have been developed within the USGS, including the NWS Quantitative Precipitation Estimates archive developed by Blodgett (2013).

The National Weather Service (NWS) River Forecast Centers (RFCs) routinely use algorithms to combine radar-based precipitation estimates with other precipitation information, including rain-gage measurements and satellite estimates. The resulting Quantitative Precipitation Estimates (QPE) data typically improve the accuracy of the radar precipitation products (Kitzmiller and others, 2013). RFCs archive the QPE data in several formats, including GRIdded Binary (GRIB) format, shapefile, and Network Common Data Format (NetCDF). Available QPE data are distributed hourly by individual RFCs, and data for the entire United States are provided online by the Advanced Hydrologic Prediction Service (AHPS) (National Weather Service, 2014). The GRIB format is the World Meteorological Organization's standard for distributing gridded precipitation data and typically is used by the NWS to provide weather-related gridded measurements and forecasts (National Centers for Environmental Prediction, 2005). The approximately 4-kilometer (km) mesh-length gridded QPE data are produced using Hydrologic Rainfall Analysis Project (HRAP) projection, which uses a polar stereographic projection and a spherical datum (Fulton, 1998).

A near real-time streamflow-simulation modeling system has been developed by the USGS in cooperation with the DuPage County Department of Engineering, Stormwater

Figure 1. Location of Salt Creek and West Branch DuPage River Basins in Illinois, and the corresponding NEXRAD grid cells used for the DuPage County Hydrologic Simulation ProgramFortran precipitation data input to the streamflowsimulation modeling system.

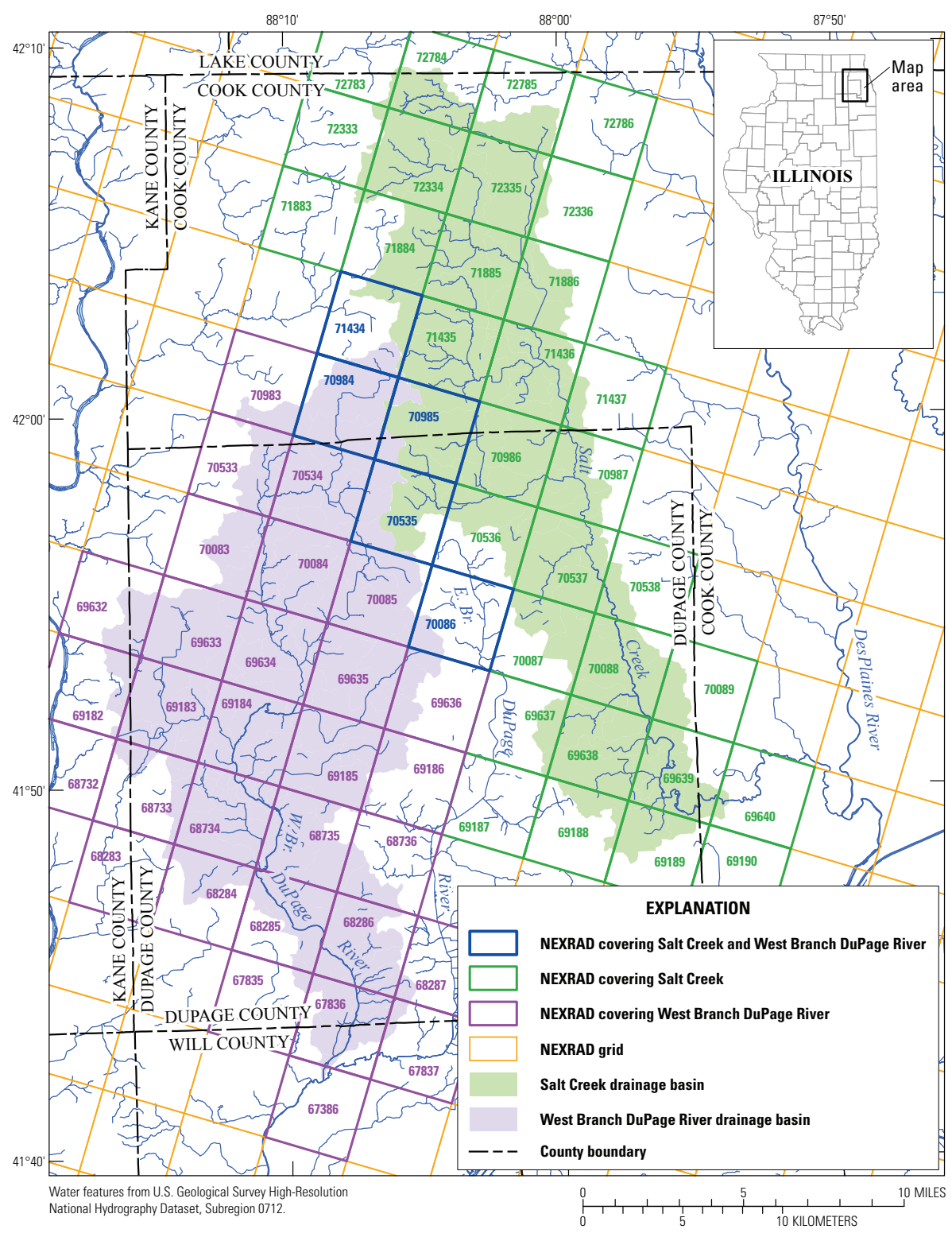


Management Division (Ishii and others, 1998) in Illinois for a headwater basin (Salt Creek) to evaluate operation scenarios of flood control structures. The DuPage County streamflow-simulation modeling system incorporates a continuous rainfallrunoff model, the Hydrologic Simulation Program-FORTRAN (HSPF) (Bicknell and others, 2001) linked to the Full Equations (FEQ) (Franz and Melching, 1997) model for dynamic-wave routing. Currently (2015), the streamflow-simulation modeling system is being enhanced, tested, and applied to a second headwater basin (West Branch DuPage River) in DuPage County (fig. 1).

A tipping-bucket rain-gage network (27 gages) and the Next-Generation Radar (NEXRAD)-QPE data produced by the North Central RFC (NCRFC) provide two different precipitation datasets for generating streamflow estimates (Over and others, 2007). The streamflow-simulation modeling system is configured to run at an hourly time step using precipitation data, in hundredths of an inch.

The USGS Illinois Water Science Center (ILWSC) routinely converts the raw QPE GRIB data files to the HSPF hourly observations (HYDHR) format (Bicknell and others, 2001) used by the rainfall-runoff model. The raw hourly GRIB files generated by the NCRFC pertain to much of the uppermidwestern United States and consist of $450 \times 350$ HRAP grid cells. Each HYDHR data file contains data for one HRAP cell, and each of the two modeled basins in the DuPage County streamflow-simulation modeling system are represented by multiple cells (36 cells for Salt Creek Basin and 35 cells for West Branch DuPage River Basin; fig. 1). NEXRAD cell numbers and the corresponding GRIB file row data referenced by Perl scripts are specific to the NCRFC regional grid. The final HYDHR formatted files remain in the original HRAP approximately 4-km projection, and files are given an arbitrary file extension (.hsp). The following steps explain the processes performed by the ILWSC to convert the GRIB formatted files to the final HYDHR format:

1. Obtain hourly NEXRAD-QPE GRIB formatted data from the NCRFC Secure File Transfer Protocal (SFTP) site (sftp.crh.noaa.gov in /data/Outgoing/ ncrfc/mpe/ as of August 2015);

2. Convert the GRIB formatted files to ASCII text files using the WGRIB program (National Weather Service, 2005); and

3. Parse through NCRFC regional gridded files using a Perl script and amass only the HRAP cells required for the DuPage County streamflow-simulation modeling system (71 total cells). The data are converted from Metric units to Inch/Pound units (millimeters to hundredths of an inch), and output files are written as ASCII text files using the HYDHR format.

4. Finally, a separate Perl script synchronizes the updated HYDHR files stored on an internal server with the online website on an hourly basis for the two DuPage County basins.

As of August 2015, the DuPage County streamflow-simulation modeling system HYDHR format files for the Salt Creek Basin are available at ${ }^{1}$ http://munster.er.usgs.gov/ saltcrk/. DuPage County streamflow-simulation HYDHR format files for the West Branch DuPage River are available at http://munster. er.usgs.gov/wbranch/.

Each HYDHR file is named using the format $x x \# \# \# \#$.hsp, where $x x$ is the DuPage streamflow-simulation modeling system basin abbreviation (wb: West Branch, sc: Salt Creek), and \#\#\#\#\# is the five digit NEXRAD cell number. A shapefile of the NEXRAD HRAP grid with the cell number attributes was developed for the NCRFC region using the methods described by Reed and Maidment (1999).

The HYDHR files are used by HSPF users for data input to a direct-access, binary file containing multiple time series datasets called Watershed Data Management (WDM) files. WDM files are used by HSPF to simulate rainfall/runoff processes and can be created using separate software packagesWDMUtil and ANNIE (Bicknell and others, 2001).

\section{References Cited}

Bicknell, B.R., Imhoff, J.C., Kittle, Jr., J.L., Jobes, T.H., and Donigian, Jr., A.S., 2001, Hydrological Simulation ProgramFORTRAN, Version 12, User's Manual: Athens, Ga., National Exposure Research Laboratory, Office of Research and Development, U.S. Environmental Protection Agency, $819 \mathrm{p}$.

Blodgett, D.L., 2013, New Service Interface for River Forecasting Center derived quantitative precipitation estimates: U.S. Geological Survey Fact Sheet 2013-3035, 2 p., http://pubs.usgs.gov/fs/2013/3035.

Franz, D.D., and Melching, C.S., 1997, Full Equations (FEQ) Model for the solution of the full, dynamic equations of motion for one-dimensional unsteady flow in open channels and through control structures: U.S. Geological Survey Water-Resources Investigations Report 96-4240, 258 p.

${ }^{1}$ Specific site URL is subject to change.
Fulton, R.A., 1998, WSR-88D polar-to-HRAP mapping: Silver Spring, Md., National Weather Service, Office of Hydrology, Hydrologic Research Laboratory Technical Memorandum, $33 \mathrm{p}$.

Ishii, A.L., Charlton, T.J., Ortel, T.W., and Vonnahme, C.C., 1998, Modeling system for near real-time flood simulation for Salt Creek in Du Page County, Illinois: Subcommittee on Hydrology, Interagency Advisory Committee on Water Data, Proceedings of the First Federal Interagency Hydrologic Modeling Conference, Las Vegas, p. 8.51-8.58.

Kitzmiller, D., Miller, D., Fulton, R., and Ding, F., 2013, Radar and multisensor precipitation estimation techniques in National Weather Service hydrologic operations: Journal of Hydrologic Engineering, v. 18, no. 2, p. 133-142.

National Centers for Environmental Prediction, NCEP WMO GRIB2 Documentation, 2005, Version 11.0.0, accessed May 19, 2014, at http://www.nco.ncep.noaa.gov/pmb/docs/ grib2/grib2_doc.shtml.

National Weather Service, Climate Prediction Service WGRIB, 2005, wgrib highlights, accessed May 19, 2014, at http://www.cpc. ncep.noaa.gov/products/wesley/wgrib.html.

National Weather Service, Advanced Hydrologic Prediction Service, 2014, About the precipitation analysis Page, accessed May 19, 2014, at http:/water.weather.gov/precip/ about.php.

Over, T., Murphy, E., Ortel, T., and Ishii, A., 2007, Comparisons between NEXRAD radar and tipping-bucket gage rainfall data: A case study for DuPage County, Illinois: World Environmental and Water Resources Congress 2007, p. 1-14, doi: 10.1061/40927(243)274.

Reed, S., and Maidment, D., 1999, Coordinate transformations for using NEXRAD data in GIS-based hydrologic modeling: Journal of Hydrologic Engineering, v. 4, no. 2, p. $174-182$.

By Terry Ortel and Ryan Spies, U.S. Geological Survey

For more information concerning this report, contact:

Director, Illinois Water Science Center

U.S. Geological Survey

405 North Goodwin Avenue

Urbana, IL 61801-2347

dc_il@usgs.gov

Phone: (217) 328-USGS (8747)

Fax: (217) 328-9770

or visit our Web site at:

http://il.water.usgs.gov/ 